\title{
A New Conceptual Framework for Business Model Analysis
}

\author{
Chin-Chiuan Lin ${ }^{1 *}$, Wei-Ting Yvonne Foung ${ }^{2,3}$ \\ ${ }^{1}$ Department of Business Administration, Kun Shan University, Tainan, Taiwan \\ ${ }^{2}$ Chairman of ECAIC Integrated Consulting Co., Ltd., Taichung, Taiwan \\ ${ }^{3}$ Institute of Human Resource Management, National Sun Yat-Sen University, Kaohsiung, Taiwan \\ *Corresponding author. Email: cclin@mail.ksu.edu.tw
}

\begin{abstract}
The present study proposed a new conceptual framework (supply-interface-demand, SID) for analysing a business model. The new conceptual framework analysed the business model from the demand side of the customer to the supply side of the suppliers, and the transaction interface was also analysed. The SID framework not only can analyse the existing business model, but also can develop a new business model for the enterprises based on the problem improvement of the existing business model. The present study also conducted taxi business as the sample to illustrate the analysis of existing business model and to develop a new business model. Keywords: Conceptual framework, Business model, Supply-interface-demand
\end{abstract}

\section{INTRODUCTION}

Whether for a century-old or a new start-up enterprise, the business model is the critical factor to the success of the enterprises. Groesser and Jovy [1] proposed that it doesn't matter whether the company is a small or a global enterprise, the business model is regarded as the most important part of the company. Therefore, many researches [2][3][4][5] have focused on analysing the business model. Shafer et al. [6] reviewed the definition of business model and suggested that business model represents the basic core of logic and strategic choice of the companies to create and obtain value in the network. Therefore, the business model reflects the choice strategy for achieving the company's management goals in the market competition [7].

For business model analysis, Johnson et al. [2] proposed a theoretical model to analyse the basic business model (Figure 1), which includes the interaction between key processes, key activities, and profit models, and the mutual promotion of customers' value orientation. Furthermore, the key resources are assets, personnel, technology, products, facilities, sales channels, and brands. These assets can provide a value proposition for target customers.

The customer value proposition and profit model respectively define the value of the customer and the company; key resources and key processes also describe how to create value for the customers and the company [2].

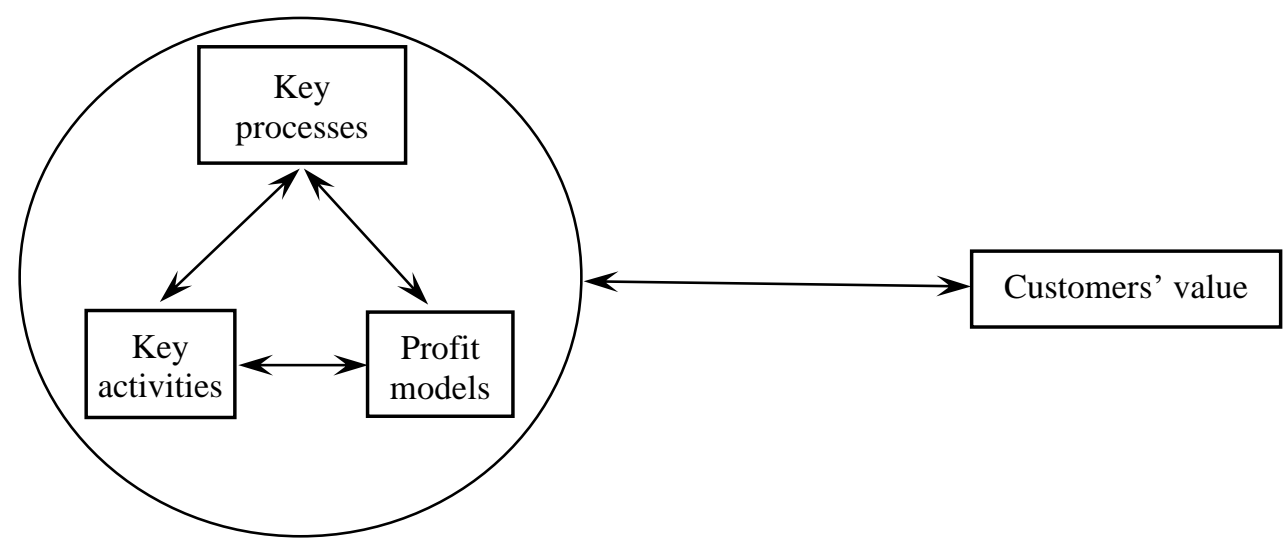

Figure 1 Theoretical model of the basic business model [2]

Osterwalder \& Pigneur [3] proposed a nine building blocks (Figure 2) that describes the business model rationale on how an organization creates, delivers, and captures the business values.
The nine building blocks are described as follow:

(1). Customer segment: The organization serves one or several customer groups. 
(2). Value proposition: It is committed to solve the customers' problems and satisfy the customers' needs through a value proposition.

(3). Channel: The value proposition is delivered to customers by communication, distribution, and sales channels.

(4). Customer relationship: Establish and maintain customer relationships with each customer group.

(5). Revenue stream: The source of income comes from the value proposition successfully provided to customers.
(6). Key resource: The key resources are the assets needed to provide and deliver the above elements.

(7). Key activities: These are the most important measures the company must take.

(8). Key partnership: Some activities are outsourced and some resources are obtained inside the company.

(9). Cost structure: Business model elements lead to cost structure.

\begin{tabular}{|c|c|c|c|c|}
\hline \multirow{2}{*}{$\begin{array}{l}\text { Key partners } \\
\text { (KP) }\end{array}$} & Key activities (KA) & \multirow{2}{*}{$\begin{array}{l}\text { Value proposition } \\
\text { (VP) }\end{array}$} & Customer relationship (CR) & \multirow{2}{*}{$\begin{array}{l}\text { Customer segments } \\
\text { (CS) }\end{array}$} \\
\hline & Key resources (KR) & & Channels $(\mathrm{CH})$ & \\
\hline
\end{tabular}

Figure 2 The nine building blocks of business model analysis architecture

Osterwalder \& Pigneur [3] also pointed out seven aspects of business model innovation: senior managers, intrapreneurs, entrepreneurs, investors, consultants, designers and serious entrepreneurs.

(1). Senior executive: Build new business models in old industries.

(2). Intrapreneur: Help develop the latest technology through the right business model.

(3). Entrepreneur: Solve unsatisfied customers' needs and build new business models around them.

(4). Investor: Invest in companies with the most competitive business models.

(5). Consultant: Help customers question their business models, imagine and establish new business models.

(6). Designer: Find a suitable business model to launch innovative products.

(7). Conscientious entrepreneur: Bring positive social and economic changes through innovative business models.

Afuah [8] provided a relatively simple visualization method, of which the content of the model is customers' value proposition, resources and activities, market segmentation, growth model, and revenue model.

Afuah [8] also investigated how organizations use innovation in business models to take advantage of the following entrepreneurial opportunities: crowdsourcing and open innovation, long tails, social media, disruptive technologies, less innovation, network effects, and the lack of complementary capabilities.

Latora et al. [9] proposed a decision support tool, which can modify the AHP process for value model level analysis based on nine building blocks for business model analysis [3].

For start-up business model analysis, Foss and Saebi [5] engaged in business model innovation and further research, such as sustainability, open innovation, and dynamic capabilities, and start-up companies must address important survival conditions, which is a viable business model [10]. Slávik [10] pointed out that understanding the structure of business model and its impact on the business performance of start-ups may increase their likelihood of survival.

Fritsch \& Wyrwich [11] represented in the context of regional knowledge and corporate culture, and explored emerging companies.

Koch [12] noted that in the IT start-up model, its efficiency depends on scarcity and personalization. When starting a new business, any entrepreneurial behaviour means choosing a business model [5]. However, they did not clarify the structure and consequences of the start-up business model.

Osterwalder et al. [4] indicated that the business model canvas can help you create value for your business, and the value proposition canvas can help you create value for your customers. When setting up a new venture, Osterwalder et al. [4] further pointed out the main challenges and opportunities faced by new enterprises as follows: provide evidence that your ideas can be run within a limited budget; manage investor participation; the risk of no money before; find the right value proposition and business model; the main opportunity to use rapid decision-making and agility to gain advantage; use ownership motivation as the driving force of success. What followed then was a start-up company that continued to work hard to confirm its existence and operated under very limited and dramatic conditions, and the expected result was that the product was accepted by the market and brought huge returns to investors.

Slávik [10] analysed the business phase in the development phase of the model through the nine building blocks proposed by Osterwalder \& Pigneur [3], and pointed out that with the improvement of entrepreneurial thinking, the business model has improved its development level.

Business model innovation (BMI) by treating business models as variables rather than constants, is possible to provide established companies with possible returns on competitive profit levels [13].

Trapp et al. [14] also defined BMI as the process of integrating new business logic into established companies to improve profitability or take advantage of new business 
opportunities. However, compared with business model upgrades or specific product innovations, existing research has limited understanding of BMI.

Trapp et al. [14] also developed a BMI identification tool and outlined the essence of the business model according to the definition of management science, which will be valuable to enterprise innovation managers and provide suggestions on how to strengthen the innovations.

Furthermore, Euchner and Ganguly [15] pointed out that business model is not only a mean for an enterprise to create and obtain customers' value, but also focuses on creating customers' value by considering the competitive advantage. Otherwise, it will make the enterprise vulnerable to profit erosion and weak growth. Therefore, this research attempted to establish a new conceptual framework to analyse the business models based on enterprise-level supply, transaction interfaces, and customers' needs.

\section{LITERATURE REVIEW}

\subsection{Framework of Supply-Interface-Demand}

Figure 3 shows the conceptual framework of supplyinterface-demand (SID) for business model analysis which is proposed by the present study.

\begin{tabular}{|c|c|c|}
\hline Supply & Interface & Demand \\
\hline Who & Cash flow & Who \\
\hline When & Information flow & When \\
\hline Where & Intermedium & Where \\
\hline What & Service provision & What \\
\hline Why & Guarantee & Why \\
\hline How & Interactive & How \\
\hline How much & Etc. & How much \\
\hline
\end{tabular}

Figure 3 Supply-interface-demand framework for business model analysis

\subsection{Description of Supply-Interface-Demand}

From the perspective of consumers, consumption is triggered by consumers' demand. The supply side, transaction interface and demand side for business model analysis consideration is described below:

Supply side: Generally, we can analyse the supply side by who, when, where, what, why, how, and how much. The taxi driver provides the taxi and service to the consumers. The provided service duration depends on the drivers' available time.

Transaction interface: The transaction interface analysis items generally includes cash flow, information flow, intermedium, service provision, guarantee, interactive, ...etc.

Demand side: We also can analyse the supply side by who, when, where, what, why, how, and how much. The people when they need to move to another place, they will start their demand of taxi services.

\section{EXAMPLE OF ANALYZING A TAXI'S BUSINESS MODEL}

The present study takes the taxi operation business model in Taiwan as a sample to illustrate the SID framework from the formerly Taxi Business Model A (about 50 years ago, Table 1) to advance to present Taxi Business Model D (present day, Table 4). Furthermore, the present study also tried to develop the future Taxi Business Model E (Table 5) based on the analysis from Model A to Model D.

\subsection{Taxi Business Model A (Formerly)}

Table 1 shows the SID analysis of formerly Taxi Operation Business Model A and the scenario, supply side (taxi driver) problem, interface and demand side (customer) problem in this model are shown as follows:

Existing business model: Formerly Taxi Business Model A. Scenario: The taxi drivers drove the car around on the street and waiting for passengers to wave their hand to call the taxi service.

Supply side (taxi driver) problem: The taxi driver might be taking long time to find a customer, and further, the taxi driver might not find a customer during all day. Furthermore, the taxi driver's gas fee cannot be recovered and gets no income.

Interface problem: (1) The information flow is the customers wave their hand, if the taxi drivers doesn't see and no taxi around the customers, the customers cannot get taxi service. (2) Passengers might encounter bad drivers, and drivers might also encounter bad passengers, there is no guarantee for both parties. (3) The cash flow is pay cash, this might have some problems along the way, such as: counterfeit money and robbery. (4) The service provision type is passive. (5) There is time limit for supply and demand side of the transaction.

Demand side (customer) problem: The customers (passenger) might wait for a long time to find a taxi, and further, the customers might not find a taxi during all day. 
Table 1 SID Analysis of Taxi Business Model A (Formerly)

\begin{tabular}{|l|l|l|l|l|l|}
\hline \multicolumn{2}{|c|}{ Supply } & \multicolumn{2}{c|}{ Interface } & \multicolumn{2}{c|}{ Demand } \\
\hline Who & Taxi driver & Cash flow & Pay cash & Who & General customer \\
\hline When & Day-time & Information flow & Wave hand & When & Day-time \\
\hline Where & On the street & Intermedium & Eye & Where & On the street \\
\hline What & Taxi & Service provision & Passive & What & Transportation \\
\hline & & Guarantee & No & How & Taxi \\
\hline & & Interactive & Direct & & \\
\hline
\end{tabular}

\subsection{Taxi Business Model B (Advanced Formerly)}

The Taxi Business Model B solves the problem of taxi business model $\mathrm{A}$ that the taxi driver might not find a customer for all day and the customers might not find a taxi for all day. Table 2 shows the SID analysis of Taxi Business Model B and the scenario, supply side (taxi driver) problem, and interface problem in this model are shown as follows:

Existing business model: Former Taxi Business Model A + Taxi Business Model B.

Scenario: The taxi drivers are waiting at the train station, airport and hospital etc. When the customers go out from the train station, airport, and hospital, they can take the taxi service immediately. This can solve the problems between the taxi drivers and customers. The train station, airport, and hospital, are the business flow platform for taxi drivers and customers.

Interface problem: (1) Passengers might encounter bad drivers, and drivers might also encounter bad passengers. There is no guarantee for both parties. (2) The cash flow is pay cash, this might have some problems along the way, such as: counterfeit money and robbery. (3) The service provision type is still passive. (4) There is time limit for supply and demand of transaction.

Demand side (customer) problem: If the customers are not in the business flow platform, they also might not find a taxi during all day.

Table 2 SID Analysis of Taxi Business Model B (Advance Formerly)

\begin{tabular}{|l|l|l|l|l|l|}
\hline \multicolumn{2}{|c|}{ Supply } & \multicolumn{2}{c|}{ Interface } & \multicolumn{2}{c|}{ Demand } \\
\hline Who & Taxi driver & Cash flow & Pay cash & Who & General customer \\
\hline When & Day-time & Information flow & Wave hand & When & Day-time \\
\hline Where & Fixed place + on the street & Intermedium & Eye & Where & Fixed place + on the street \\
\hline What & Taxi & Service provision & Passive & What & Transportation \\
\hline & & Guarantee & No & How & Taxi \\
\hline & & Interactive & Direct & & \\
\hline
\end{tabular}

\subsection{Taxi Business Model C (Present)}

The Taxi Business Model $\mathrm{C}$ solves the problem of Taxi Business Model B if the customers are not at the taxi station. Table 3 shows the SID analysis of Taxi Business Model C and the scenario and interface problem in this model are shown as follows:

Existing business model: Taxi Business Model B + Taxi Business Model C, while the Taxi Business Model A is die-out.

Scenario: When the customers need a taxi, they call to the taxi company and tell the designated place, the taxi company then broadcasts it to the taxi drivers to request respond by radio. After taxi driver has responded, the taxi company than send feedback about the taxi number and arrival time to the customer. This way can improve the safety for both taxi drivers and customers, because the taxi company has the transition records. The taxi company is equivalent to be the thirdparty guarantor.

Interface problem: (1) The service provision type is also passive. (2) There is a need regarding clear address of designated place. If the customers cannot describe the clear address, then the taxi drivers cannot provide taxi service.

Demand side (customer) problem: If the customers are not at the taxi station and do not have a clear address, the customers also might not find a taxi for all day. 
Table 3 SID Analysis of Taxi Business Model C (Present)

\begin{tabular}{|l|l|l|l|l|l|}
\hline \multicolumn{2}{|l|}{ Supply } & \multicolumn{2}{c|}{ Interface } & \multicolumn{2}{c|}{ Demand } \\
\hline Who & Taxi driver & Cash flow & Cash or card & Who & General customer \\
\hline When & 24 hours & Information flow & Telephone & When & 24 hours \\
\hline Where & Designated place & Intermedium & Taxi company & Where & Designated place \\
\hline What & Taxi & Service provision & Passive & What & Transportation \\
\hline & & Guarantee & Yes & How & Taxi \\
\hline & & Interactive & Indirect & & \\
\hline
\end{tabular}

\subsection{Taxi Business Model D (Advanced Present: Uber)}

In 2014, Damodaran [16] found that Uber had released the App on which consumers can submit their request for taxis, which is then the Uber will transfer the service demand to the contracted private car owner. And then these private car owners take orders and provide taxi services.

The Taxi Business Model D solves the problem of the Taxi Business Model $\mathrm{C}$ if the customers do not have a clear address. Table 5 shows the SID analysis of Taxi Business Model D and the scenario and interface problem in this model are shown as follows:

Existing business model: Taxi Business Model B + Taxi Business Model C + Taxi Business Model D.
Scenario: When the customers need a taxi, they open the App on their cell phone to request the taxi. The manager of the App then transfers the information (customers' position) to their taxi drivers. The available taxi drivers then response and take the order, and then the responded taxi driver's information is replied to the customers. The taxi driver then picks the customers according to the GPS information.

Interface problem: (1) The service provision type is also passive. (2) When the general public apply to provide the service and apply the transportation demand in the App, it is unable to verify the applicants in order to ensure the customers' safety.

However, the Taxi Business Model D solves many problems for customers and taxi drivers, such as: cash flow, information flow, and service provision.

Table 4 SID Analysis of Taxi Business Model D (Advanced Present: Uber)

\begin{tabular}{|l|l|l|l|l|l|}
\hline \multicolumn{2}{|l|}{ Supply } & \multicolumn{2}{c|}{ Interface } & \multicolumn{2}{c|}{ Demand } \\
\hline Who & General public & Cash flow & Online & Who & General customer \\
\hline When & 24 hours & Information flow & App & When & 24 hours \\
\hline Where & GPS coordinate & Intermedium & App manager & Where & GPS coordinate \\
\hline What & General car & Service provision & Passive & What & Transportation \\
\hline & & Guarantee & Half & How & General car \\
\hline & & Interactive & Indirect & & \\
\hline
\end{tabular}

\subsection{Taxi Business Model E (Future)}

The main emphasis and spirit of Taxi Business Model E is to provide the services proactively. Table 5 shows the SID analysis of Taxi Business Model E and the scenarios of taxi business in this model are shown as follows:

Existing business model: Taxi Business Model E provides proactive provision service to increase business opportunities.

Scenario: When the customers have requested the taxi several times, the APP manager then has the customers' information for analyzing the customers' behavior. Then the APP manager can proactively remind the customers if they need a taxi service. If the customers' responses are positive, then the APP manager then assigns the taxi which is near the customers.

Interface problem: The safe guarantee of both customers and taxi drivers are still a problem.

However, the Taxi Business Model E improves the type of service provision is form passive to proactive which can increase the transaction opportunities and customers' convenience. 
Table 5 SID Analysis of Taxi Business Model E (Future)

\begin{tabular}{|l|l|l|l|l|l|}
\hline \multicolumn{2}{|c|}{ Supply } & \multicolumn{2}{c|}{ Interface } & \multicolumn{2}{c|}{ Demand } \\
\hline Who & General public & Cash flow & Online & Who & General customer \\
\hline When & 24 hours & Information flow & App & When & 24 hours \\
\hline Where & GPS coordinate & Intermedium & App & Where & GPS coordinate \\
\hline What & General car & Service provision & Proactive & What & Transportation \\
\hline & & Guarantee & Yes & How & General car \\
\hline & & Interactive & Indirect & & \\
\hline
\end{tabular}

\section{CONCLUSION}

The present study used the Taxi Business Model as a sample to illustrate the SID framework from the formerly Taxi Business Model A to advanced present Taxi Business Model D. Furthermore, the present study also developed the future Taxi Business Model E according to the problem analysis of the previous models.

The results indicate that the SID framework which is proposed by the present study cannot only analyze the existing business models, but can also develop new business models for enterprises on the basis of improving the existing business model problems.

\section{REFERENCES}

[1] S. Groesser, N. Jovy, Business model analysis using computational modelling: A strategy tool for exploration and decision-making. Journal of Management Control, 27 (2016) 61-88.

[2] M.W. Johnson, C.M. Christensen, H. Kagermann, Reinventing your business model. Harvard Business Review, 86(12) (2008) 57-68.

[3] A. Osterwalder, Y. Pigneur. Business model generation: A handbook for visionaries, game changers, and challengers. Hoboken, New Jersey: John Wiley \& Sons, 2010.

[4] A. Osterwalder, Y. Pigneur, C.L. Tucci, Clarifying business models: Origins, present, and future of the concept. Communications of the Association for Information Systems, 16 (2005).

[5] N.J. Foss, T. Saebi. Fifteen years of research on business model innovation: How far have we come and where should we Go? Journal of Management, 43 (2017) 200-227.

[6] S. Shafer, H. Smith, J. Linder, The power of business models. Business Horizons, 48(3) (2005) 199-207.
[7] S. Nenonen, K. Storbacka, Business model design: conceptualizing networked value co-creation. International Journal of Quality and Service Sciences, 2(1) (2010) 43-59.

[8] A. Afuah. Business Model Innovation: Concepts, Analysis, and Cases. New York: Routledge, 2014.

[9] A.G. Latora, L. Compagno, N. Trapani, A decision support tool for business models analysis. International Journal of the Analytic Hierarchy Process, 10(2) (2018) 219-242.

[10] S. Slávik, The business model of start-up: structure and consequences. Administrative Sciences, 9(69) (2019) $1-23$.

[11] M. Fritsch, M. Wyrwich, Regional knowledge, entrepreneurial culture and innovative start-ups over time and space: An empirical investigation. Small Business Economics, 51 (2018) 337-353.

[12] O. Koch, Business model development in it startups: the role of scarcity and personalization in generating user feedback. ECIS 2015 Completed Research Papers, 107 (2015) 1-18.

[13] K.I. Voigt, Special topic: Strategic innovations. Review of Managerial Science, 5(4) (2011) 263-264.

[14] M. Trapp, K.I. Voigt, A. Brem, Business models for corporate innovation management: Introduction of a business model innovation tool for established firms. International Journal of Innovation Management, 22(1) (2017) 1850007-1-1850007-24.

[15] J. Euchner, A. Ganguly, Business model innovation in practice: A systematic approach to business model innovation can help capture value and reduce risks. Research-Technology Management, 57 (2014) 33-39.

[16] A. Damodaran, A disruptive cab ride to riches: The Uber payoff, 2014. 